\title{
GEOTHERMIC POWER IN ITALY
}

\begin{abstract}
$\mathrm{T}$ $\mathrm{HE}$ formation of a large company in ItalyLarderello S.A. per lo Sfrut tamento delle Forze Endogene-with a capital of 54, and perhaps later of 150 , million lire, for utilizing the natural heat sources of Italy, may well be regarded as a consummation of the life work of Prince Ginori Conti. $\mathrm{He}$ is honorary president of the new company which has taken over many of his patents together with his company, the Societa Boracifera di Larderello; and among other distinguished people on the board of directors is Dr. G. Fauser, the inventor of the wellknown electrolytic cell.

In a small book published last year, Prince Conti described his new and well-equipped laboratory for research in this field, which he says dates back to 1906 , and is a continuation of "the long and noble tradition" originating with Höfer who, in 1777, discovered boric acid in the Lagon Cherchiaio di Nonterotondo. In 1916 was established the first and still probably the only Centrale Geotermica in the world, developed later into a Supercentralo of some $90,000 \mathrm{kw}$. The yield of gas and fume from the fumaroles (Ital. fumaioli or fumaruoli) and soffioni has increased very remarkably from a fow hundred thousand kilos to two million kilos of fume or vapour per hour, besides enormous quantities of gas. The latter occurs in the proportion of about 30 litres gas to 1 kilo of fume, and consists of 93 per cent carbon dioxide, $2 \cdot 5$ per cent hydrogen sulphide, and combustible residue the composition of which is approxi.
\end{abstract}

mately 38 per cent hydrogen, 39 per cent methane, $22 \cdot 6$ per cent nitrogen, together with small proportions of helium, neon, argon, krypton, and xenon.

A well-equipped research station has for some time been engaged on the analysis and industrial possibilities of these various products.

The work is under the personal supervision of Prince Conti, with the assistance of his son, Dr. Giovanni- Ginori Conti, Prof. Umberto Sborgi and other distinguished Italian men of science and engineers. Tho organization comprises library, administrative offices, and various departments for chemical, physical, geological, mineralogical, geophysical, and seismographical investigations, not only in connexion with the fumaroles and soffioni but also of the 'boric acid fields' around Larderello. Since the operations of the new company extend to the whole of Italy other similar research stations will doubtless be established in other districts, with Larderello as headquarters. Provision is made, inter alia, for highand low-temperature and high-pressure investigations, the former ranging from $-254^{\circ}$ to $2000^{\circ} \mathrm{C}$. and the latter up to 1000 atmos. Semi-large scale working is also included, and a pilot plant has been installed for dealing with $150 \mathrm{cu}$. m. per hour. Among the principal items in the research programme at present are the recovery of helium and other rare gases, also of hydrogen, methane, and a synthesis gas mixture of hydrogen and nitrogen, presumably for ammonia production and derivatives, such as nitric acid, etc.

\section{TRAINING OF ENGINEERS}

$\mathrm{I}^{\mathrm{N}}$ $\mathrm{N}$ the June issue of the Journal of the Institution of Civil Engineers is published the record of a joint informal meeting of the three Institutions-Civil, Mechanical and Electrical-at which Mr. 'T. G. Rose introduced tho subject "The Importance of a Training in Management for Engineers". Following the two claims (1) that the fundamental principles governing sound industrial management were now sufficiently clearly defined to be teachable, and (2) that a knowledge of these principles would be of advantage to an engineer in the pursuit of his profession, he indicated several systems on which the desired instruction might be given.

That the need of this is keenly realized was made evident by the brisk discussion, but the views ex. pressed were very divergent as to how and when the training should be given. Some considered that it could only be usefully imparted to those who had had experience, while others held that the principles could be taught at an early stage. One suggestion was that the threo Institutions should arrange lectures and meetings at which the problems of industrial management would bo discussed by practical men. This would, no doubt, provide a finishing courso which could be read and studied by all those, wherever situated, who had already been taught the fundamental principles. No clear indication was given as to the method of providing this elementary instruction, but there was a suggestion that it might form part of the production side of the National Certificate scheme. This, however, is already heavily burdened and a littlo consideration will show that, unless the subject is made optional, it will to some proportion of the students be a dis. tinctly unwelcome one forced upon them.

In the same issue of the Journal it is interesting to note the intimation that the Council will promote a conference on engineering education and training during the course of next session and has invited the universities and other bodies to appoint representatives to form a general organizing committee. The time is ripe for such a conference, for it is nearly thirty years since the last, and one would expect that, to ensure steady development, five-yearly conferences would be held. At present it is very largely left to the colleges themselves to devise systems and curricula, and the several branches of the profession tako but a perfunctory interest in a matter so closely affecting them. In consequence, there is a very large class of students whose interests are wholly neglected by the Institutions. This class consists of all those who are outside the reach of the recognized colleges, and for whom some authoritarian training should be envisaged as at present is provided for those more fortunately placed. Some responsibility rests on those who control the National Certificate arrangements in respect of the thousands of students who are, in effect, barred from them. 